\title{
Indigenous Horticultural Crops of India for Immunity Development
}

\author{
L. C. De ${ }^{1 *}$ and Tulipa De ${ }^{2}$ \\ ${ }^{1}$ ICAR-NRC for Orchids, Pakyong, Sikkim, India \\ ${ }^{2}$ UBKV, Pundibari, Cooch Behar, west Bengal, India \\ *Corresponding author
}

\section{A B S T R A C T}

\begin{tabular}{|l|}
\hline Ke y w o r d s \\
$\begin{array}{l}\text { Underutilized, } \\
\text { Fruits, Vegetables, } \\
\text { Medicinal plants, } \\
\text { Antioxidants }\end{array}$ \\
\hline Article Info \\
$\begin{array}{l}\text { Accepted: } \\
\text { 21 May 2020 } \\
\text { Available Online: } \\
\text { 10 June 2020 }\end{array}$ \\
\hline
\end{tabular}

Keywords

Underutilized,

Fruits, Vegetables,

Medicinal plants,

Antioxidants

Article Info

Accepted:

Available Online:

\begin{abstract}
Most of the indigenous fruits are underutilized and are rich in vitamin, minerals, nutrients and has medicinal potential. Many traditional or underutilized vegetables are characterized by a high nutritional value compared with global vegetables like tomato and cabbage. As source of essential vitamins, micronutrients, protein, antioxidants and other phytonutrients, traditional vegetables, underutilized legume crops, spices and medicinal plants have the potential to play a major role in strategies to attain nutritional security. In the present review, 16 fruit crops, 19 vegetable crops, 2 ornamental plants and more than 20 medicinal plants of Indian origin having capacity to develop immunity of individuals is discussed.
\end{abstract}

\section{Introduction}

Currently underutilized food sources ranging from minor grains and pulses, root and tuber crops and fruits and vegetables to non-timber forest products have the great potential to make a substantial contribution to food and nutrition security, to protect against internal and external market disruptions and climate uncertainties, and lead to better ecosystem functions and services and thus enhancing sustainability (Elbert, 2014). Most of the indigenous fruits are underutilized and are rich in vitamin, minerals, nutrients and has medicinal potential. Many traditional or under-utilized vegetables are characterized by a high nutritional value compared with global vegetables like tomato and cabbage. As source of essential vitamins, micronutrients, protein, antioxidants and other phytonutrients, traditional vegetables and underutilized legume crops have the potential to play a major role in strategies to attain nutritional security (Keatinge et al., 2011).

India is a native of a number of underutilized fruits such as Aonla, Ber, Carambola, Rose apple, Karonda, Mangosteen, Latka, Paniala, Sitaphal, Bread fruit, Mulberry, Ramphal, Phalsa, West Indian Cherry, Hog Plum, Bakul, Pumelo, Wild Mango, Chalta, Durian, 
Jalpai, Elephant apple, Bael, Jangli Badam, Sweet Tamarind, Mahua, Kendu, Vella, Dampe, Jamun, Wild date, Star Goose Berry, Monkey Jack, Gol pata, Mangrove Apple, Water Chestnut, Chironji, MiricaTenga, Rabab, Kodak, Kolu, Emppe, Tader, Indian Chest Nut, Tayek, etc. North Western and Eastern Himalayan region is rich in diversity of leek, shallot, other alliums, asparagus, spinach, chenopods, amaranths, chilli, bean, horse radish, colocasia, parsley, chow-chow and Cyclanthera pedata. North-Eastern region is blessed with underutilized solanaceous vegetables, leafy vegetables, legume vegetables like winged bean, jack bean, sword bean and cucurbits like chow chow and meetha karela. Gangetic plains harbour minor vegetables like cucurbits and aquatic leafy vegetables. The Indus Plains is enriched with biodiversity in amaranth, Cucumis, Chenopodium, Momordica and Citullus. The Central region is rich in minor cucurbits like melon, bitter gourd, pointed gourd and ridge gourd. Underutilized vegetables possess a vast potential to eradicate the curse of malnutrition by providing high calorie value food to the poor. India is enriched with 8000 species of medicinal plants of which the Ayurveda system of medicine uses about 700 species, Unani 700, Siddha 600, Amchi 600 and modern medicine around 30 species.

Fruit crops (De and Bhattacharjee, 2008)

\section{Aonla/amalaki/amla/ Indian goose berry (Emblica officinalis)}

Aonla is a native deciduous fruiting plant grown in many states of India. The tree is hardy, prolific bearer and a suitable choice for arid regions of the country. Amla is the most concentrated form of vitamin C (500$600 \mathrm{mg} / 100 \mathrm{~g}$ ) found in the plant kingdom, and when the whole fruit has been found to have great antioxidant properties. It also contains proteins and minerals like calcium, phosphorus and iron. The high vitamin $\mathrm{C}$ content of fruit makes its wide use in Ayurvedic medicine. The tree has been regarded as sacred in India, worshipped as the Mother Earth and is believed to nurture humankind by its nourishing taste and also believed to stimulate purity. It is used as a rejuvenative to promote longevity, enhance digestion, treat constipation, reduce fever, purify the blood, reduce cough, alleviate asthma, strengthen the heart, benefit the eyes, stimulate hair growth, enliven the body, and enhance intellect. In Ayurvedic poly-herbal formulations, Amla is a common constituent, and most notably is the primary ingredient in Chyawanprash, triphala. It is used for making chutney, murrabba, candies, pickles, powder, etc. It is also used in inks, shampoos and hair oils. It grows well in subtropical dry climate although reported its presence in hilly regions. Successfully propagated by patch or modified ring budding. Common varieties are 'Banarasi', 'Chakaiya', 'Francis', 'Kanchan', 'Krishna', 'NA-6', 'NA-7', 'NA-10'. A budded/grafted aonla tree starts bearing third year onwards after planting, whereas a seedling tree may take 6-8 years. An aonla tree may bear $100-300 \mathrm{~kg} /$ tree, giving $15-20$ tonnes/ha.

\section{Black mulberry (Morus nigra)}

Native to Western Asia. Trees are 8-12m tall with a compact crown and heart shaped leaves. Fruits are black, large, juicy, rich in sugar (9\%), malic acid and citric acid and eaten fresh or processed into jam, wine or dry fruits. The leaves are considered as antibacterial, astringent, diaphoretic, hypoglycaemic, odontalgic and ophthalmic. They are used in the treatment of colds, influenza, eye infections and nosebleeds. The fruit is used in the treatment of urinary incontinence, tinnitus, premature greying of the hair and constipation in the elderly. The root bark is antitussive, diuretic, expectorant 
and hypotensive. It is used internally to treat asthma, coughs, bronchitis, oedema, hypertension and diabetes. The bark is anthelmintic and purgative and can be used to expel tape worms. Popular varieties are 'Black Persian', 'Kaestar', 'Riviera', 'Shangri-La'.

\section{Chironjii or lanzan (Buchanania lanzan)}

It is a deciduous tree, upto $20 \mathrm{~m}$ tall. Fruits are greenish white sessile red, brown or black in dried state. Fruits are one seeded and nonendospermic. Both fruits and seeds are edible. They are commonly used in sweets in India. However, they are also ground into powders for thickening savory sauces and flavouring butters, and stewed into rich, meaty kormas. It is used in the treatment of fever, blood related problems, thirst, ulcer, burning sensations. It is laxative, aphrodisiac, cardiotonic and astringent to bowels. Leaf juice is digestive, expectorant, aphrodisiac, purgative, blood purifier, whereas seeds are used in the preparation of heart and brain tonic, stomachic and febrifuge. The tree produces a gum benzoin. The gum obtained from stem is used for dyeing and printing cloth.

\section{Citron (Citrus medica)}

It is native to North-East India. Commonly grown in Sikkim, Western Ghats, M.P., U.P., Himalayan ranges and Punjab for it's edible fruits. These are small trees or shrubs, $3 \mathrm{~m}$ tall with stout spines. Leaflets are oblong or elliptic, upto $17.5 \mathrm{~cm}$ long, petioles not winged. Flowers are small, reddish tint and borne in 4-10 per cluster. Fruits are yellow, ovoid-oblong and large upto $30 \mathrm{~cm}$ long, thick rinded and juicy, sour in taste. It is used by tribal for medicinal purpose. It is popular for it's thick rind which is candied. Ripe fruits are potent antiscorbutic, stomachic, cardiac tonic, stimulant, sedative, analgesic and used in dyspepsia, bilious vomiting, cold, fever, palpitation, sore throat, cough, asthma, thirst, hiccough and earache .Root is analgesic, antispasmodic and used in diarrhea, piles and constipation. Seeds are anthelmintic, stomachic, sedative, cardiac tonic and useful in palpitation; flowers and buds are astringent and used in blood disorders and peels are anthelmintic. Leaves are useful to induce sleep. Fruit extracts have also shown good antioxidant activity.

\section{Indian almond (Terminalia catappa)}

It requires a tropical climate in full sun, moist and well-drained soil. Trees are tolerant to salt and drought. Plants thrive along sea shore. They require frost-free climate for their growth and development. It is a tropical tree, $35 \mathrm{~m}$ tall with an upright symmetrical crown, horizontal branches, ovoid glossy dark green and leathery leaves which turn into pink red or red-yellow in winter due to pigments such as violaxanthin, lutein and zeaxanthin. The green white female and male flowers are borne on the same tree i.e. monoecious. The fruit is drupe, green, yellow or reddish and oval in shape and containing a single seed. Plants are generally propagated from seeds. The kernels are edible and oily. Leaves are used in the treatment of liver diseases, dysentery and diarrhoea. Leaves have anticarcinogenic and anti-oxidant properties. Kernels are administered in the treatment of sexual problems. Tropical almond is used by the breeders for tropical aquarium fishes to keep them healthy. The bark and unripe fruits are used for tanning. Black dye is obtained from fruits.

\section{Jackfruit (Artocarpus heterophyllus)}

It belongs to the family Moraceae. Originally, jackfruit is a native of India and presently cultivated throughout the tropical low land areas. Trees are large with oblong, oval or elliptical glossy, leathery and dark green leaves. Juvenile leaves are lobed. These evergreen trees attain a height upto $15 \mathrm{~m}$. 
Separate male and female inflorescences are borne on specialized laterals. Male flower heads appear on new wood among the leaves or above the female. The female heads appear on short, stout twigs that emerge from the trunk and large branches or even from the base of very old tree. The stalks of both male and female flower heads are encircled by a small ring. Tree bears largest borne fruit in the world weighing upto $38 \mathrm{~kg}$. The fruits are very large with sharp protuberances, which are of multiple type, the endocarp is thick and fused with mesocarp, aromatic and rich in latex. The exterior of the compound fruit is green or yellow at the ripening. The inner portion consist of large edible pulps of yellow, banana flavoured fresh that embeds a smooth oval, light brown seed. There may be 100 or 500 seeds in a single fruit, which are viable for not more than 3 to 4 days. Jack fruit is commonly propagated from seeds. Seeds are sown in polybag or nursery immediately after extraction. Soaking seeds in 25ppm NAA or $50 \mathrm{ppm} \mathrm{GA}_{3}$ for $24 \mathrm{~h}$ enhances germination.

Air layering, inarching, epicotyl grafting and chip, patch or forket budding are other means of vegetative propagation of jack fruit. Fruits are rich in carbohydrate, protein, vitamin $\mathrm{C}$ and minerals like $\mathrm{Fe}, \mathrm{P}, \mathrm{K}$ and $\mathrm{Ca}$. Immature fruits are used as vegetables. Unripe fruits are made into pickle and slices. Ripe fruits are used for preparation of dried products, canned products, pulp, beverage, jelly, and nectar. The rind may be used for making jelly, the skin of ripe fruits and leaves are used as cattle feed. The seeds can also be boiled or roasted and eaten like nuts. The ripe bulbs are fermented and the distilled, produce potent liquor. Starchy flour is made from seeds. Seeds are popular ingredients in many cooked preparations. The roots and leaves possess medicinal properties. Hot water extracts of leaves are given to diabetic patients. The fruit parts contain pectin, the extracted pectin can be used for food industry. The latex from the bark of the tree contains resins, and is often used to plug holes in the earthen containers. Timber is used for making furniture and construction works. Esters and aliphatic alcohols have been extracted from the distillate of jackfruit. Popular varieties are 'Bhadaiyan', 'Bhusila', 'Champaka', 'Gulabi', 'Handia' ,'Hazari', 'Khaja', 'Rudrakshi', 'Safeda'. The hybrids are 'Burliar-1', 'PLR-1', 'PPI-1'.

\section{Kokam (Garcinia indica)}

It is native to East Indies. Cultivated in South India and Maharashtra. Trees are large, borne with small apple sized fruits. Fruits are acidic with purple sour taste and made into a vinegar. Seed oil is used to adulterate butter. Fruits are edible and useful in cooling effect during summer. It reduces indigestion, acidity, flatulence, constipation and diarrhoea. This is an important immunity booster because it is rich in anti-oxidants and it possesses anti-viral, anti-bacterial and antihelminthic properties.

\section{Phalsa (Grewia asiatica)}

It is a subtropical plant, can be grown upto an elevation of $900 \mathrm{~m}$ above sea level. Plants are deciduous, hardy, tolerant to higher temperature upto $44^{\circ} \mathrm{C}$ and freezing temperature for a few days. High temperature helps in ripening of fruits. These are large shrubs or small trees, upto $4.5 \mathrm{~m}$ tall with long, slender drooping branches. Fruits are round, produced in branched clusters on peduncles. Skin of fruits turn from green to dark purple when ripe. Flesh is soft, greenish white stained with purplish red near the skin. The flavour is grape like acidic in nature. Large fruits are two seeded while small fruits are single seeded. Phalsa is commercially propagated through seeds. July-August is the best time for sowing of seeds. Besides, it can also propagated through hard wood cuttings and air layering with the application of 
growth regulators like IBA and NAA. Plants are allowed to develop a bushy habit. Annual pruning to a height of $90 \mathrm{~cm}$ to $120 \mathrm{~cm}$ from the ground level encourages new shoot growth and increase fruit yield than severe pruning. Fruits are rich in vitamins $\mathrm{A}, \mathrm{C}$ and minerals like $\mathrm{Fe}$ and $\mathrm{P}$. Fruits contain $55 \%$ juice with $11-12 \%$ TSS and $3 \%$ acidity. Flowers contain grewinol. The seeds contain a bright yellow oil having $8.3 \%$ palmitic acid, $11.0 \%$ stearic acid, $13.4 \%$ oleic acid, $64.5 \%$ linoleic acid. Fruits are eaten fresh or made into syrup and commercially used in the preparation of soft drinks. Leaves are used as fodder. The bark is used as a soap substitute in Burma. The fruit is astringent and stomachic. Unripe fruits are administered against in respiratory, cardiac, blood disorders and fevers. The bark infusion is used as a demulcent, febrifuge and treatment for diarrhoea. The wood is used for golf shaft. The root is effective in curing rheumatism.

\section{Pummelo/ jambura (Citus grandis)}

It is the largest citrus fruit and belongs to the family Rutaceae. It is also known as "Shaddock" and locally called "Jambura". It is native to China. Trees are spiny, upto $10 \mathrm{~m}$ tall spreading with large broad winged hairy leaves. Leaflets are oblong-obovate to elliptic, upto $20 \mathrm{~cm}$ long. Flowers are large borne in single or clusters. Fruits are very large, yellow at ripe, white or pink fleshed, thick skinned, puffy and less juicy and borne singly. Seeds are monoembroyonic. Fruits sometimes may attain a size of $10 \mathrm{~kg}$. Fruits are sweet and moderately juicy. Two types, viz. white fleshed and red or pink fleshed are available in India and cultivars are named accordingly. The fruits are eaten fresh or processed into juice. Pummelo fruit is also an excellent source of vitamin A, B and C. It is recommended in traditional herbal medicine as source of diabetic medication. It is well known for their various ethno-medicinal uses.
It is used in folk medicine in many countries as antimicrobial, antioxidant, larvicidal, hepatoprotective, anticancer, antiplatelet, antidiabetic and anti-inflammatory. It can cure fever, gout, arthritis, kidney disorders and ulcers. The fruits pulp and peels are useful as an appetizer, stomach-tonic, inflammation, cardiac stimulant and coughs. The fruit juice is used in stomach tubules. The fruit is nutritive, cardiotonic and refrigent. The seeds are employed against dyspepsia, coughs and lumbago whereas fruits are used in the treatment of coughs, fevers, cardiotonic, cancer and gastrointestinal disorders. Popular varieties are 'Hirado Buntan', 'Kao Pan', 'Kao Phuang', 'Large Red Fleshed', 'Large White Fleshed', 'Pink Sensation', 'Walter', 'Chakaya'.

\section{Soe-phie (Myrica nagi)}

These are evergreen trees, 4-10m tall, dioecious, with lanceolate or elliptic ovate, leathery leaves crowded towards the end of branches; and small, sessile, pistillate flowers. Male inflorescence is much branched borne in a compound raceme. Fruits are globose, succulent drupe, ellipsoid and papilliferous and red colour when ripe. It grows wild upto an elevation of $2000 \mathrm{~m}$ above sea level. It performs best in Pinus roxburghii forest where its density increases with Pinus tree biomass. The flowering season starts from the first fortnight of October and continue till the second fortnight of December. Fruiting season starts from the $1^{\text {st }}$ week of March and continues till last week of the June. Fruits are small, seedy and sweet with a pleasant blend of acid. Local people are used to eat fruit with salt as fresh and for making the pickles. Fruit juice and pulp are used for making jam and jelly. Barks, flowers, fruits and roots are used in Ayurvedic medicines for the treatment of anaemia, asthma, bronchitis, coughs, colds, dysentery, fever, piles, sores, throats problems, ulcers and urinary infections. 


\section{Sohiong (Prunus nepalensis)}

It is an important indigenous nutritionally rich lesser known fruit of temperate area. The fruit is locally called as Sohiong in Khasi (Meghalaya). The tree is medium to tall, evergreen grown to a height of $15-20 \mathrm{~m}$. It starts bearing fruits after seven year of planting. Flowers are white, borne in terminal racemes or auxillary. Fruit are drupe, fleshy, dark purple in colour at full ripe and green to pinkish colour in immature stage. Fruit surface is smooth round. Usually fruit shape resembles like black grapes. Stone is hard, round in shape with smooth surface but some other genotypes grown in mid hills having rough stone surface and seed looks just like peach. The stone size varies with genotype. Flowering period varies from November to March and fruit ripen in July to early October depending on the altitudinal variation. It is naturally distributed in East Khasi Hills, West Khasi hill and Jaintia hills district of Meghalaya between 1500 and $2000 \mathrm{~m}$ altitude. The highest diversity of Sohiong trees are observed in East Khasi Hills District. It is distributed in Khadar shnong area comprising of villages like Dewlieh, Nongstraw, Wah Sohra, Diengsong, Tyngiar, Mawtuli, Kshaid, Phong Shnongpdei, Kharang, Krohiawhiar, Puhbsein and Nohshut. It is also observed in Mawsynram, Mawkynrew, Mylliem, Mawphlang, Mawklot, Pynursla, Pongkung, Mawryngkneng areas. Some trees are also found in adjoining areas of Shillong in isolated manner. It is mostly grown in homestead yard and as a subsidiary crop in the orchards of pear. Fruit is eaten as fresh by the local people and fruit juice and pulp are used for the preparation of squash, jam, RTS and cheery wine. Quality parameters of fruit showed that the TSS of fruit ranged from 16 to $23.20 \%$, acidity $0.13-0.77 \%$, ascorbic acid 8.81-12.34 mg/100 g pulp weight and sugar
3.53 to $10.37 \%$. Fruits are astringent, antioxidant and anti-hepatotoxic. Leaves are diurectic and used for edema.

\section{Star goose berry (Phyllanthus acidus)}

The star gooseberry is one of the few members of the Euphorbiaceae family that has edible fruit. It is found in southern parts and in Northeastern parts particularly in Mizoram. This is an attractive and spectacular shrub or tree, 2-9 $\mathrm{m}$ tall, with spreading, dense, bushy crown having rough, main branches. Flowers are dioecious or monoecious, borne in solitary or 2 in axillary fascicles, with many bracts. The fruit is oblate with 6 to 8 ribs; pale-yellow to nearly white when fully ripe; waxy, fleshy, crisp, juicy and highly acidic. The tree often yields fruits twice a year in South India, the first in April and May, and the second in August and September. In other parts, the main crop is obtained in January with scattered fruiting throughout the year. The star gooseberry thrives well in subtropical to tropical climate, being sufficiently hardy to survive. It performs up to an elevation of $914 \mathrm{msl}$. The tree grows best in moist soils. The tree is generally propagated by seeds but may also be multiplied by budding, greenwood cuttings or air layering. Seedlings produce a satisfactory crop in 4 years. The average fruit weight $3.39 \mathrm{~g}$, fruit length $1.57 \mathrm{~cm}$, fruit diameter $1.94 \mathrm{~cm}$, pulp recovery $95.28 \%$, seed weight $0.16 \mathrm{~g} / \mathrm{seed}$, seed length $0.58 \mathrm{~cm}$, seed diameter $0.62 \mathrm{~cm}$, TSS $4.68 \%$, acidity $2.27 \%$ and ascorbic acid $21.15 \mathrm{mg} / 100 \mathrm{ml}$ juice is recorded. It used to treat a wide spectrum of diseases such as inflammatory, rheumatism, bronchitis, asthma, respiratory disorder, hepatic diseases and diabetes.

West Indian cherry (Malphigia punicifolia)

A medium sized shrub, $4 \mathrm{~m}$ tall, drought resistant and distributed in West Bengal, Assam and Tripura. A full grown tree yields 
upto $10-15 \mathrm{~kg}$ fruits annually. Frutis are small, berry sized and bright red. Fruits are rich sources of vitamin $\mathrm{C}$ even 65 times more than that of oranges and other nutrients and used as fresh or for flavouring drinks, ice cream and juices. It is used for the common colds, diarrhea, liver problems and vitamin $\mathrm{C}$ deficiency.

\section{Wild date palm (Phoenix sylvestris)}

Native to India and Sri Lanka. It is a tall palm. Fruits are edible and rich sources of carbohydrate, phenol, amino acids, flavonoids, tannins, alkaloids, terpenoids, fibres, vitamins and minerals. Sap tapped from inflorescence is used to make wine or sugar. The palms are cultivated in M.P., A.P. and Karnataka. It is antipyretic, cardiotonic, laxative, diuretic and antioxidant.

\section{Wild strawberry (Duchesnea indica)}

A perennial prostrate vine with silky hairs on the stem, runners growing all round and roots touch the ground. Fruits are etaerios of achenes, red, like strawberry with spirea red flesh surrounded by large persistent calyx. It grows well under sun or partial shade. Creeping vines thrive in wasteland although they prefer a well-drained soil. Plants are hardy and cold tolerant. These are easily propagated through seeds or by division of runners. Seeds take one month at $15^{\circ} \mathrm{C}$ to germinate. For propagation division of the runners is made during spring or late summer. On an average, a vine produces about $150 \mathrm{~g}$ fruits annually. Fruits are edible, rich in vitamin and minerals but low amount of sugar and liked by children. Fruits lack sweetness and have a flat taste. The whole plant is anticoagulant, antiseptic, depurative and febrifuge. Crushed leaves are used as poultice on swellings. An infusion of the flowers is used to activate blood circulation. The fruit is used to treat skin diseases. Being a creeper, the plants are grown as a good cover plant.

\section{Wood apple/kaith (Feronia limonia)}

The tree can be grown upto an altitude of $1000 \mathrm{~m}$ from sea level. It is said to require a monsoon climate with a distinct dry season. It prefers a light drained soil. It is one of the hardy tree of arid and subarid region. Can be grown in wasteland. A small slow growing tree, upto $9 \mathrm{~m}$ tall, spiny and deciduous. The fruit is round to oval upto $7.5 \mathrm{~cm}$ in diameter, with a hard, woody, greyish, scurfy coverings. The pulp is brown, mealy, odorous, resinous, astringent, acid or sweetish with small numerous white seeds. The wood apple is generally propagated from seeds. Multiplication through root cuttings, air layers or by budding into self-seedlings is advised to induce dwarfness and precociousness. Fruits are rich in in pectin, unsaturated fatty acids. Unripe fruits contain $0.015 \%$ stigmasterol. The fruit pulp contains $18 \%$ carbohydrate, $7 \%$ protein, $4 \%$ fat, $5 \%$ fibre and $2 \%$ mineral matter as well as vitamin $\mathrm{C}$, niacin, thiamin, riboflavin etc. Leaves contain stimasterol and bergaten. The bark contains $0.016 \%$ marmesin. Root bark contains aurapten, bergapten, isopimpinellin and other coumarins. The scooped pulp which is sticky is eaten raw with or without sugar, or is blended with coconut milk and palm sugar syrup and drunk as a beverage or frozen as an ice cream. It is also used in chutneys and for making jelly and jam. Nectar can be made by diluting the pulp with water. The rind of fruits can be curved and used as a utensil such as a bowl or ashtray. The trunk and branches exude a white transparent gum which is used in making artists, water colors, ink, dyes and varnish. Gum is used as a substitute of gum Arabic. Heartwood is valued for making of agricultural implements, rollers for mills, carving, rulers and other products. The fruit is used as a liver and cardiac tonic and when ripe, as an astringent to halt diarrhoea and 
dysentery and as an effective treatment for hiccough, sore throat and diseases of gum. Juice of young leaves is mixed with milk and sugar candy and prescribed as a remedy for biliousness and intestinal troubles of children. Leaves, barks, roots and fruit pulp are all used against snakebite.

Vegetables (De and Bhattachrjee, 2010)

\section{Amaranth (Amaranthus tricolor)}

It is an annual or rarely perennial plant and characterized by small, often green or reddish flowers arranged in dense clusters, stems. Leaves are simply, opposite to alternate, with coarsely toothed or entire margin and exstipulate. The flowers are solitary or aggregated in cymes, spikes or panicles and bisexual and actinomorphic. The fruits are dry, indehiscent and one seeded. Amaranth is a warm season crop, grown well in hot humid climate. Being a C4 plant, it has good capacity to utilize full sunlight and has rapid, short growth cycles, high net assimilation rate, a low $\mathrm{CO}_{2}$ compensation point and a low transpiration coefficient. It grows well in well drained loamy soils with a $\mathrm{pH}$ of 5.5 to 7.5. In Northern India, it is grown during Feb-March or June-July. In mild tropical climate, it can be grown throughout the year. Seeds are sown about $20-30 \mathrm{~cm}$ apart and seedlings are spaced $10 \mathrm{~cm}$ apart after doing needful thinning. The seed rate should be kept $2-3 \mathrm{~kg}$ per hectare. The amaranths are harvested either by pulling out with roots or by periodical cuttings. The first cutting becomes ready one month after sowing or transplanting and subsequent cuttings are made at 7-10 days intervals. On an average, it yields about 50-70 tonnes leaf and stem per hectare. Leaves are used as vegetables. Leaves and seeds are rich source of vitamins like vitamin $\mathrm{A}, \mathrm{K}, \mathrm{B}_{6}$, vitamin $\mathrm{C}$, riboflavin, folic acid and minerals like $\mathrm{Ca}, \mathrm{Fe}$, $\mathrm{Mg}, \mathrm{P}, \mathrm{K}, \mathrm{Zn}, \mathrm{Cu}$, and $\mathrm{Mn}$. Both seeds and leaves of amaranth contain higher amount of protein including amino acid lysine. Regular intake of amaranth reduces hypertension, cardiovascular disease, blood pressure and cholesterol levels. Popular varieties are 'Arka Arunima', 'Arka Suguna', 'Badi Chaulai', 'Chhoti Chaulai', 'Co-2', 'Co-3', 'Co-4', 'Co5', 'Co-I', 'Krishnasree', 'Lal Sag', 'Pusa Kiran', 'Pusa Kirti', 'Pusa Lal Chaulai', 'Renusree'.

\section{Bleeding heart (Clerodendrum colebrookianum)}

A shrub or small tree, $1.5-3 \mathrm{~m}$ tall with robust yellow brown branchlets. Leaves are ovate or elliptic cordate, papery. Inflorescences are borne in terminal corymbose cymes. Fruits are blue-green, sub-globose. It grows naturally on forests or on mountain slopes upto an elevation of $2000 \mathrm{~m}$ and distributed in Bangladesh, India, Indonesia, Malayasia, Myanmar, Nepal, Thailand and Vietnam. A common medical plant used against rheumatic pains by Khasi and Jaintia tribes of Meghalaya. Roots with bark and leaves are effective in coughs, dysentery \& asthma. The leaves are vermifuge. Decoction provides relief in high blood pressure. Young leaves and tender shoots used as vegetables and in soups.

\section{Brihati (Solanum indicum)}

It is an erect prickly undershrub, $0.5-1.5 \mathrm{~m}$ tall, distributed in India, Sri Lanka, Malayasia, China, Philippines. Leaves are tinged with purple, ovate and lobed. Flowers are borne in racemose cymes with short peduncles and prdicels; blue in colour. Fruits are globose, orange-yellow when ripe and glabrous. The fruit is eaten as vegetable in curry preparation and chutney. Seeds, roots, leaves and berries are used against bronchitis, asthma, cough, dysuria, leucoderma, sexual disorders, insomnia, cardiac weakness and rhinitis. 


\section{Chekurmanis / katuk / sweet leaf bush (Sauropus androgynus)}

It is a shrub, $2.5 \mathrm{~m}$ tall with multiple upright stems and dark green oval leaves. It is grown well under shade and moist situation upto an elevation of $500 \mathrm{~m}$. Propagated by means of seeds or by cuttings. The herbaceous stem cuttings of 5-6 nodes are planted in polybags containing sand, soil and FYM in equal proportion. The leaves contain $7.4 \%$ protein, vitamin $\mathrm{A}, \mathrm{B}, \mathrm{C}, \mathrm{D}, \mathrm{F}$ and $\mathrm{K}$. Tender leaves and shoots are used as green vegetables mixed with potato or mashed flour for preparation of paratha or chapathi. It is used as ingredient of idli and dosa. The young leaves and tips are eaten raw in salads. The flowers and the young berries are also used in food. Traditionally, leaves are used in the treatment of genitor-urinary diseases, cardio-vascular diseases and other ailments like eye vision and skin problems. Leaves have good antioxidant properties.

\section{Curry leaf (Murraya koengii)}

A small tree, 4-6m tall with pinnate leaves. The leaves are highly aromatic. The flowers are small, white and fragrant. Berries are small, shiny and black. It grows well in warm tropical and subtropical climate under full sun to partial shade. The soil should be allowed to thoroughly dry between waterings. The plants are fertilized during active growth period. During winter, watering is done very sparingly. Propagated by small suckers, root cuttings or by seeds. Planting is done during rainy season. Seedlings or suckers are planted at a spacing of $4 \mathrm{~m}$ x 4m. Well rotten FYM @ $10 \mathrm{~kg} /$ pit is applied for better establishment. Leaves become ready for harvest 15 months after planting and can be continued upto the age of 20-25 years. The average yield is 20-25 tonnes /ha. The fresh leaves contain $6.1 \%$ protein, $1 \%$ fat, $16 \%$ carbohydrate, $6.4 \%$ fibre, $4.2 \%$ minerals, vitamin $\mathrm{A}, 2-3 \mathrm{mg} / 100 \mathrm{~g}$ nicotinic acid and $4 \mathrm{mg} / 100 \mathrm{~g}$ vitamin $\mathrm{C}$. Leaves are rich in a crystalline glucoside 'Koenigin'. A glucoside 'Murrayin' is obtained from the flowers. Leaves are used to improve the taste and flavour of foods. The fruits are very sweet and eaten fresh. The leaves, barks and roots are used as a tonic and a stomachic. The bark and the roots are used as a stimulant. The green leaves are consumed raw for curing dysentery and diarrhoea. The branches are said to strengthen the gum and the teeth.

\section{Drumstick (Moringa oleifera)}

A small shrub or tree, upto $12 \mathrm{~m}$ tall and fast growing. The leaves are bi- or tripinnate, alternate and spirally arranged on twigs. Flowers are bisexual, yellowish white borne on slender spreading or drooping axillary clusters. The fruits are pendulous, linear, three sided pods with nine longitudinal ridges. It is mainly grown in semi-arid, tropical and subtropical climate. It prefers sandy red soils, sandy loam or loam or black soils of $\mathrm{pH}$ 6.07.5. It is a drought tolerant plant. In south India, Nov-Dec and in Northern India, JuneJuly is the best time for planting. Propagated through seeds or stem cuttings. One year old stem cuttings of $1.0-1.5 \mathrm{~m}$ long and $14-16 \mathrm{~cm}$ in girth is used. Stem cuttings are planted 3$5 \mathrm{~m}$ apart. Leaves are rich in beta-carotene, vitamin $\mathrm{C}$, protein and iron. The leaves are cooked and eaten with spinach. Sometimes, leaves are dried and crushed into a powder and used in soups and sauces. Seeds contain $38-40 \%$ oil. Drumstick seeds are aphrodisiac. The flowers are cooked to make a delicate food after mixing with green peas and potato. The triangular ribbed pods with winged seeds are used as vegetables. In south India, it is used for the preparation of Sambar. It can be preserved by canning. It can be made into a variety of curries, dishes by mixing with coconut, poppy seeds and mustard. The leaves 
are reported to have a stabilizing effect on blood pressure and to control glucose levels. They are also used to treat anxiety, diarrhoea and inflammation of the colon, skin infections, scurvy, intestinal parasites and many other ailments. The oil is non-drying, resists rancidity, and is used for cooking, lubrication, and in the cosmetic industry. The leftover pressed cake or ground moringa seeds are used to purify drinking water and to flocculate contaminants. The wood can be used for dying (blue color). The coarse fibre of the trunk is suitable for making mats, cordage, and paper. Popular varieties are 'Chavakacheri Muringai', 'Chemmunengai', 'Jaffna Type', 'Kattumurungai', 'Kodikalmurungai', 'Palmurungai', 'PKM-1', 'Punamurungai', 'Yazhphanam Muringa'.

\section{Indian pennywort / thankuni / gotu kola (Centella asiatica)}

A small herbaceous annual with slender stems, creeping stolons of green to reddish green in colour. Leaves are stalked, reniform shaped with round apices having palmately netted veins and are borne on pericladial petioles. The rootstalks containing rhizomes grow vertically down, creamish in colour and covered with root hairs. Flowers are pinkish to red in colour and borne in small umbel near the surface of the soil. Fruits are densely reticulated. It grows naturally along ditches and low land areas in sunny or slightly shaded location. Susceptible to frost. Easily propagated through seeds. A moist fertile sandy loam soil is ideal. It can be grown upto an elevation of $2500 \mathrm{~m}$, cold hardy and can tolerate as low as $-10^{\circ} \mathrm{C}$. Other method of propagation is by division. Used as leafy green vegetables and a traditional component to rice and curry. Leaves are used in the sweet 'pennywort drink'. In Indonesia, the leaves are used as salad. In Vietnam and Thailand, leaves are used for preparing a drink or eaten in raw form in salads. In India, it is used as a component of summer drink 'thandaayyee'. Gotu Kola is anti-bacterial, anti-viral, antiinflammatory, anti-ulcerogenic, anxiolytic, a cerebral tonic, a circulatory tonic, a diuretic, nervine and vulnerary. The decoction of juice from leaves is reported to relieve hypertension. The juice is used as a general tonic for good health. It is used to revitalize the brain and nervous system. The herb is rich in vallarine, asiaticoside, sitosterol, tannin and oxy-asiticoside. Asiaticoside is used in the treatment of leprosy. According to Siddha literature, leaves are used in the treatment of syphilis, all types of fevers, children's abdominal disorders, elephantiasis and hydrocele.

\section{Indian spinach (Basella alba)}

It is a fast growing perennial, soft stemmed, $10 \mathrm{~m}$ long with narrow and lance shaped leaves and white flowers borne in clusters on elongated spikes. It grows well in warm and humid climate and rich soil. Application of nitrogenous fertilizer is useful. The plant is highly sensitive to frost. A temperature of 25 to $30^{\circ} \mathrm{C}$ is ideal for it's growth. Basella is usually propagated through seeds but stem or root cuttings are also used. Seeds are generally sown during June-July or September-October. About 12-14 kg seeds are required for planting of one hectare of land. Seeds are sown directly or seedlings are raised and transplanted. During June-July, cuttings are planted. For getting higher yields, the plants are trained on stakes or bowers. Vegetatively propagated crops give early yield than seeds propagated crops. On an average, it is easy to harvest 15-20 tonnes stem tips of $25-30 \mathrm{~cm}$ long from one hectare. Tender leaves and shoots are used as vegetables. Leaves are rich in protein, iron, vitamin $\mathrm{A}$, vitamin $\mathrm{C}$ and calcium. The succulent mucilage is a rich source of soluble fibre and useful as a thickener in soups and stews. The ripe berries are used for the 
extraction of colouring dyes. The plant contains the essential amino acids like arginine, iso-leucine, leucine, lysine, threonine and tryptophan along with several vitamins, minerals and a low percentage of soluble oxalates. Major biological activities are androgenic, anti-diabetic, antiinflammatory, anti-microbial, antioxidant, anticancer, antiviral, CNS depressant, hepatoprotective and wound healing properties due to presence of beta - sitosterol and lupeol in the plant.

\section{Kachari (Cucumis callosus)}

It is a hardy monoecious plant. Fruits are small, egg shaped and sub-globose. At immature stage, fruits are green and bitter in taste but turns to pale yellow and sweet at ripening. A warm arid climate and a well drained sandy loam soil are ideal for its cultivation. Popular varieties are AHK-119, AHK-200. Seeds are sown in February-March or June-July in furrows at a spacing of $1.5 \mathrm{~m}$ $2.0 \mathrm{~m} \times 60 \mathrm{~cm}$. About $2.0-2.5 \mathrm{~kg}$ seed is required for one hectare of land. It removes 20-25 tonnes FYM, $80 \mathrm{~kg} \mathrm{~N}, 40 \mathrm{~kg} \mathrm{P}_{2} \mathrm{O}_{5}$ and $40 \mathrm{~kg} \mathrm{~K} 2 \mathrm{O}$ per hectare. Summer season crops are given 5-6 light irrigations. Fruits are harvested at mature stage. It yields 10-12.5 tonnes/ha. Mature fruits are consumed in the form of cooked vegetables, chutney and pickles.

The dehydrated kachari is diuretic, gastric stimulant, cooling refrigerant, coughicide and wormicide. It is effective in digestion, facial paralysis, debility, bile, obesity, piles, constipation and cough.

\section{Kantakari (Solanum xanthocarpum)}

It is a prickly, usually spreading or diffused perennial, woody at the base with hairy branches. The leaves are $10 \mathrm{~cm}$ in length, with sharp yellow prickled. The flowers are purple and borne in small bunch opposite the leaves.
The fruits are glabrous, globular drooping berries and yellow or pale with green veins. Fruits contain a glucoalkaloid termed as 'Solanocarpine'. It is useful in the treatment of bronchial asthma, cough, worms etc. The fruits facilitate the seminal ejaculation, alleviate worms, itching, fever and reduce fats.

\section{Latjira/chirchita (Achyranthes aspera)}

An erect perennial or annual herb, $60-80 \mathrm{~cm}$ tall with slender rambling branches, elliptical leaves and greenish white flowers borne on terminal spikes. Fruits are utricle, oblongcylindrical, truncate at apex and reddish brown. It grows in wastelands as weeds. It is tolerant to heat and prefers a sandy soil under the shade of trees. Plants are easily propagated by seeds or root cuttings. Leafy and seeds are used as vegetables. Seeds are rich in protein, cooked and eaten. Plants yield achyranthine and bitter, pungent, heating, laxative stomachic, carminative and useful in the treatment of vomiting, bronchitis, heart disease, piles, itching abdominal pains, ascites, dyspepsia, dysentery, blood disease etc.

\section{Lingura (Diplazium esculentum)}

It is distributed in Uttarakhand and Sikkim Himalaya. Boiled fronds are cut and fried in cooking oil with spices such as seeds of Cleome viscosaL. Fresh fronds are very high in antioxidant, vitamin-A, vitamin $\mathrm{C}$, potassium, copper and carotenes. The rhizomes are kept in the granaries to check them from insect and pests. Young fronds are used as green vegetables and also used as salad or cooked as vegetables. Decoction of the plant is sued in coughs and as tonic.

\section{Patharchur (Coleus aromaticus)}

It is a large succulent aromatic perennial herb with hispidly villous or tomentose 
fleshy stem. Leaves are simple, opposite, broadly ovate, crenate and fleshy. Flowers are pale purplish in dense whorls at distant intervals borne in a long slender raceme. Fruits are orbicular or ovoid nutlets. The leaves of the green type of country borage are often eaten raw with bread and butter. The chopped leaves are also used as substitute for sage in stuffing. Coleus aromaticus is used for seasoning meat dishes and in food products, while a decoction of its leaves is administered in cases of chronic cough and asthma. It is considered to be an antispasmodic, stimulant and stomachic and is used for the treatment of headache, fever, epilepsy and dyspepsia. It is used to treat in indigestion, diarrhoea, nervous tension, insect bites, toothache, earache, rheumatism, whooping cough, and bronchitis.

\section{Punarnava / pigweed / hogweed (Boerhaavia diffusa)}

It is a perennial creeping prostrate or ascending herb, $1 \mathrm{~m}$ tall having spreading branches. The roots are stout and fusiform. The stem is prosprate, woody or succulent, cylindrical, purplish, hairy and thickened at nodes. Leaves are simple, thick, fleshy, hairy, arranged in unequal pairs, green and glabrous above and pinkish white underneath. Leaves are ovate oblong, round or subcordate at the base with wavy, smooth and undulating margin. Flowers are tiny borne in small bracteolate umbels forming axillary and terminal panicles. Flowers are hermaphrodite, pedicellate and white, pink or pinkish red in colour. It is found naturally throughout the warmer parts of the country upto an altitude of $2000 \mathrm{~m}$. It grows well on waste lands and in the fields after rainy season. The plants are rich in flavanoids, alkaloids, steroids, triterpenoids, lipids, lignins, carbohydrates, proteins. Punarnavine is the main active ingredient. The herbs and roots are rich in proteins and fats. The herb contains 14 essential amino acids. Leaves are cooked and eaten as vegetables. Roots are used in the treatment of piles. The root-paste is applied to cure blood dysentery. The decoction of the plant is given in the treatment of nodules in the body. The root juice is used in treating asthma, scanty urine and internal inflammation disorders. The whole plant is useful for curing leucorrhoea, rheumatism, stomachache, high blood pressure and seminal weakness. The punarnava possesses punarnavoside which are diuretic, antiinflammatory, anti-fibrinolytic, anti-bacterial, anthelmintic, anti-nematodal and anti-viral. The flowers and seeds are used as contraceptive.

\section{Snake gourd (Trichosanthes anguina):}

A climbing annual herb with five angled stems and grooved with branched tendrils. Leaves and hairy, angular, or 5-7 lobed and dentate. Flowers are monoecious, axillary and white. Fruits are cylindrical with white waxy surface, slender tapering, 40-120 cm long and $4-10 \mathrm{~cm}$ in diameter. Flesh is white. It requires hot and humid climate and a temperature of $30-35^{\circ} \mathrm{C}$ and a sandy loam to loam soil for it's growth. Propagated by seed. On an average, 6-8 $\mathrm{kg}$ seed is required for one hectare of land. Seeds are sown in June-July at a distance of $3 \times 1 \mathrm{~m}$. A dose of $60 \mathrm{~kg} \mathrm{~N}$, $30 \mathrm{~kg}, \mathrm{P}_{2} \mathrm{O}_{5}$ and $30 \mathrm{~kg} \mathrm{~K} \mathrm{~K}_{2} \mathrm{O}$ is recommended to get first harvest 3 months after planting. The immature fruits are cooked as vegetable is salads and in various curry dishes. The fruits are rich is carbohydrates, proteins, minerals and vitamin $\mathrm{A}, \mathrm{B}$ and $\mathrm{C}$. It increases appetite acts as a tonic, stomatic and cures biliousness. The roots and seeds are anthelmintic and used in the treatment of diarrhoea, bronchitis and fever.

The popular varieties are 'Co-1', 'Co-2', 'Co4', 'Konkan Sweta', 'TA-19', The average fruit yield is $15-20$ tonnes per hectare. 
Sweet gourd/ spiny bitter gourd (Momordica cochinchinensis)

A dioecious vine with oblong large fruits weighing $40 \mathrm{~g}$ each and large white flowers. Fruits are rich in lycopene, beta-carotene, fatty acids and proteins. Fruits and leaves are used for food and medicine purposes. It grows well in hot and humid climate. Propagated by tuberous roots. Tuberous roots are taken from both male and female plants and planted in the ratio of 9:1, respectively. Immature and tender fruits are cooked as vegetables. Fruits are used for pickle preparation. It is a good source of antioxidant due to the presence of carotenoid compounds and has anticarcinogenic affects. Besides, it lowers the risk of strokes and heart diseases.

\section{Vegetable banana (Musa paradisiaca)}

It is a herbaceous perennial tropical herb, 1$10 \mathrm{~m}$ tall with large leaves of which the overlapping bases so called false trunk. Flowers develop from the centre of the crown. Only female flowers develop into banana fruit. It is grown in humid tropical to subtropical climate upto an elevation of $1300 \mathrm{~m}$. A mean temperature of $20-30^{\circ} \mathrm{C}$ with annual rainfall of $500-2000 \mathrm{~mm}$ is ideal. It cannot tolerate chilling injury at below $12^{\circ} \mathrm{C}$. At higher temperature $\left(>38^{\circ} \mathrm{C}\right)$ plants show sunscorching. A well drained organic rich soil of $\mathrm{pH}$ 4.5-7.5 is ideal. Coastal sandy loam or clay loam soil is suitable for its cultivation. Propagated through sword suckers or pieces of rhizomes. Banana is a rich source of energy, carbohydrate, fat, protein, Vitamin A, Vitamin B, Vitamin C, K, P, Ca and Fe. Used as a staple food in different countries. Green bananas are used in cooking. Banana flower is a good anti-oxidant and cooked in soups and curries. Besides, flower cures infection, slows the aging process, promotes heart health, improves digestion, promotes mental relaxation, supports menstrual health, regulates blood sugar and cures anaemia. The tender core of pseudostem is used as vegetables. The juice extract from tender core is used to remove stones from kidney, gall bladder and prostrate. Pseudostem juice is a well-known remedy for urinary disorders, diarrhoea, dysentery and flatulence.

\section{Water spinach (Ipomoea aquatica)}

A native to Asia and an aquatic or subaquatic, floating or trailing herbaceous perennial with hollow stems and long petioled fleshy leaves. Leaves are broad. The plant is grown in ponds, water bodies or paddy fields. It produces white, pink or red flowers in leaf axils. Easily propagated by cuttings. It grows well in tropical climate where the mean temperature does not go below $25^{\circ} \mathrm{C}$. Average yield is 50-60 t/ha/year. In Ayurvedic medicine, it is used to treat jaundice and liver problems. Leaves are used to treat diabetes. It is used to cure fever, jaundice, bronchitis and general debility of women.

\section{Wild coriander (Eryngium foetidum)}

An annual topical herb, $20-80 \mathrm{~cm}$ tall with pungent long leaves having toothed margins that grows in a basal rosette pattern. Flowers are borne in clusters, profuse and white in colour. Fruits are round and covered with rounded protrusions. It grows in shady and moist location and in well drained sandy loam soils. A frost free site is ideal for its cultivation. Under hot, high light and long days, it tends to bolt and flowers profusely. It can be kept in vegetative mode when treated with $\mathrm{GA}_{3}$ sprays $(100 \mathrm{ppm})$. A slow release fertilizer is effective to increase vegetative growth. Leaves are rich in vitamin A, B, C, $\mathrm{Fe}$, carotene, calcium and aliphatic aldehydes. Seeds contain sesquiterpenoids and monoterpenes. The plant is used as food flavouring and seasoning herb for dished and 
chutney. A decoction of leaves has an antiinflammatory effect and used against diarrhoea, flu, fevers, vomiting, diabetes and constipation.

\section{Ornamental plants}

\section{Balsam (Impatiens balsamina)}

The plants are 30-75 $\mathrm{cm}$ tall with hollow stems and free branches. Leaves are lanceolate, thin, pale green with serrated margins. The flowers are spurred and borne in leaf axils. Flowers may be single or double and lilac, salmon, pink, ruby, orange, scarlet,rose or purple in colour. Some of the species have the characteristics of bursting of seed pods and scattering of seeds when touched. They are good for bedding, borders, pot plants and green house plants. The plants survive well in a semi-shaded situation. A well drained rich soil is ideal. The potting mixture should contain equal parts of loam, leaf mould and sharp sand. They are easily propagated from seeds or cuttings. Seeds of all kinds require light for germination. Plug grown seedlings are transplanted in $10 \mathrm{~cm}$ pot containing 3 parts garden soil, 2 parts compost, 1 part garden sand and 1 part peat. A temperature of $18-21^{\circ} \mathrm{C}$ is maintained in greenhouse. The plants start flowering 2 to 2.5 months after sowing. They require well aeration and moderate watering for proper growth and flowering. Application of 100 ppm each of $\mathrm{N}$ and $\mathrm{K}$ at the time of watering is beneficial. Pinching of the apical portion of the plants may be practiced to make them bushy. Traditionally, it is used in Ayurveda, Unani and Siddha for various diseases and physiological conditions such as jaundice, corns, snake bite etc. Phytochemical studies indicated the presence of many valuable compounds like naphthoquinones, coumarins, phenolic acids, flavonoids, anthocyanidins and steroids. The different parts of the plants like leaves, stem juice, flower are used in various pharmacological activities such as antibacterial, antimicrobial, antifungal, analgesic, anti-inflammatory, antioxidant and antipruritic effects.

\section{Kadam (Anthocephalus cadamba)}

An umbrella shaped tree, grows upto an height of $45 \mathrm{~m}$ bearing branches arranged in tiers. Leaves are simple. Flowers are orange, small, borne in dense globose heads. The trees are grown upto an altitude of $1000 \mathrm{~m}$ above sea level at the temperature range of $15-320 \mathrm{C}$. They are tolerant to water logging. Plants are propagated by seeds. The major constituents of the plant are triterpenes, triterpenoid glycosides, flavanoids, saponins, indole alkaloids; cadambine, cadamine, isocadambine, isodihydrocadambine. The plant is effective incurring astringent, ulcer, diarrhea, fever, cough, debility, diabetes and vomiting.

\section{Medicinal plants (De, L.C., 2017)}

\section{Acid lime (Citrus aurantifolia)}

It is a much branched spiny shrub or small tree, $3-4 \mathrm{~m}$ tall. Leaves are small, ovate elliptic, upto $7.5 \mathrm{~cm}$ long, petioles are narrowly winged. Flowers are borne in cluster. Fruits are small, oval or globose, upto $7.5 \mathrm{~cm}$ long and $6 \mathrm{~cm}$ in diameter with thinned peel, greenish yellow rind, greenish pulp and acidic in taste. Juice sacs are slender with solid core. Seeds are polyembryonic, small and smooth. It requires a warm humid tropical and frost free area. Acid lime can be grown upto an altitude of $1000 \mathrm{~m}$ above sea level. Acid lime is commercially propagated through seeds. Mature fruits are collected from healthy, heavy bearer and disease free plants. Seeds are sown immediately after extraction. Besides, acid lime can be multiplied by cutting, layering or budding. Gajanimma (Citrus pennivesiculata) is used 
as rootstock followed by rough lemon. Limes are acidic in nature and are rich source of vitamin $\mathrm{C}$, citric acid, sugar, certain minerals like calcium and phosphorus. The content of Vitamin $\mathrm{C}$ is more in lime than in lemon. Lime pericarp contains essential oil $(7 \%)$ whose main constituents are citral limonene, beta pinene and fenchone (15\%). Other aromatic compounds are terpincol, basabolence and some terpenoids. Limes are used for preparation of refreshing drink, juice, cordial, flavouring food. The peels are used for extraction of essential oils. Juice is used for making of citric acid and cosmetics. Essential oils is extracted from the peel and is mainly used in confectionery, pharmaceuticals and toilet preparations. It develops the resistance of individuals to several diseases, cures wound healing and increases the health of eyes. It improves the maintenance of good dentition and keeps away toothache, dental caries, swollen gums, fragility of bones and bleeding of the gums. Lime is vital in the treatment of gastric disorders like indigestion, constipation and peptic ulcer. Popular varieties 'Arka Rasraj', 'Chakradhar', 'Kagzi Nimboo', 'PKM-1', 'Pramalini', 'Seedless Lime', 'Sel-49', 'Tahiti','Vikram'.

\section{Anantmool (Hemidesmus indicus)}

It is a perennial, slender, laticiferous, twining or prostrate, wiry shrub with woody rootstock and numerous slender, terete stems having thickened nodes. Leaves are simple, opposite, from elliptic-oblong to linear-lanceolate, variegated with white above and silvery white and pubescent beneath. Flowers are greenish purple crowded in sub-sessile cymes in the opposite leaf-axils. Fruits are slender follicles, cylindrical, $10 \mathrm{~cm}$ long, tapering to a point at the apex. Seeds are flattened, black, ovateoblong and coma silvery white. The tuberous root is dark-brown, coma silvery white, tortuous with transversely cracked and longitudinally fissured bark. The roots contain coumarin and two sterols -hemidosterol and hemidesmol - besides resins and tannins. Aerialparts of the plant contain carotenoid $(22.4 \mathrm{mg} / 100 \mathrm{~g})$, provitamin $\mathrm{A}$, vitamin $\mathrm{C}$ (27.2 mg/100 g), tannins (1.7\%), phenolics, anthocyanins, reducing and non-reducing sugars $(17.6 \%)$, and anti-nutritional factors.

The roots are useful in vitiated conditions of pitta, burning sensation, leucoderma, leprosy, skin diseases, pruritus, asthma, bronchitis, hyperdipsia, opthalmopathy, hemicrania, epileptic fits, dyspepsia, helminthiasis, diarrhoea, dysentery, haemorrhoids, strangury, leucorrhoea, syphilis, abscess, arthralgia, fever and general debility. The leaves are useful in vomiting, wounds and leucoderma. The stems are bitter, diaphoretic and laxative and are useful in inflammations, cerebropathy, hepatopathy, nephropathy, syphilis, metropathy, leucoderma, odontalgia, cough and asthma. The latex is good for conjunctivitis.

\section{Aswagandha (Withania somnifera)}

It is an erect, evergreen, tomentose shrub, 30$75 \mathrm{cmin}$ height. Roots are stout, fleshy, cylindrical, $1-2 \mathrm{~cm}$ in diameter and whitish brown in colour. Leaves are simple, ovate, glabrous and opposite. Flowers are bisexual, inconspicuous, greenish or dull yellow in colour borne on axillary umbellate cymes, comprising 5 sepals, petals and stamens each; the two celled ovary has a single style and a bilobed stigma. The petals are united and tubular. The fruit is a small berry, globose, orange red when mature and is enclosed in persistent calyx. The seeds are small, flat, yellow and reniform in shape and very light in weight. Aswagandha is a tropical crop grown well under dry climate. Aswagandha roots are rich in alkaloids, starch, reducing sugar, hentriacontane, glycosides, dulcital, withaniol acid and a neutral compound. Eight 
amorphous bases found are withanine, somniferine, somniferinine, somnine, withananine, withananinine, pseudowithanine and withasomnine. Other alkaloids reported are nicotine, tropine, pseudotropine, $3, \square-$ tigloyloxytropane, choline, cuscudohygrine, anaferine, anahygrine and others. Roots, leaves and seeds are used in Ayurvedic and Unani medicines, to combat diseases ranging from tuberculosis to arthritis. Roots are used in medicines for hiccup, several female disorders, bronchitis, rheumatism, dropsy, stomach and lung inflammations and skin diseases. Roots and paste of green leaves are used to relieve joint pains and inflammation. It is alsoan ingredient of medicaments prescribed for curing disability and sexual weakness in male. Leaves are used in eye diseases. Seeds are diuretic. It is a well known rejuvenating agent capable of imparting long life, youthful vigour and intellectual power. It improves physical strength andis prescribed in all cases of general debility.

\section{Bael/golden apple (Aegle marmelos)}

Bael is a small to mediam sized tree, $6-8 \mathrm{~m}$ in height with trifoliate aromatic leaves and strong spined stems. Flowers are bisexual, sweet scented and greyish white. Fruits are 5$7.5 \mathrm{~cm}$ in diameter, globose, oblong pyriform with grey or yellow rind, yellow orange to brown pulp. Seeds are numerous, embedded in the pulp, compressed, white and surrounded by a slimy mucilage. Seeds have woolly hairs. It is a hardy fruit crop and can be grown in arid, semi-arid or sub-tropical hot and humid climate upto an altitude of $1200 \mathrm{~m}$. Bael is usually propagated by seeds. Recalcitrant fresh seeds are sown in the nursery in June and seedlings became ready for transplanting 7 weeks after sowing. Patch or shield budding on seedling rootstock between June - July give better success. Air layering is successful under humid tropical climate. Mature green fruits are harvested for preservation. Ripe fruits are processed into nectar, squash, cidar, jam, toffee and powder. Fruits are good source of protein, mineral like $\mathrm{P}, \mathrm{K}, \mathrm{Ca}, \mathrm{Mg}$ and $\mathrm{Fe}$. Unripe dried fruits are astringent, digestive and stomachic and used to cure diarrhea and dysentery. The pulp of the fruit contains $1.8 \%$ protein, $0.39 \%$ fat and $31.8 \%$ carbohydrate, apart from minute content of carotene, thiamine, riboflavin, niacin and vitamin C. Fruits contain a furocoumarin and marmalosin, which are responsible for medicinal properties. The bark contains umbelliferone and other coumarins. The fruits are also used in making of paints. These are also used as a substitute for soap, as source of essential oils and perfumes. All parts of plants are useful. Leaves are used for worship.The mucilage of seed is a good cementing material.Yellow dye is prepared from the rind of unripe fruits. Leaves are made into a poultice and used in the treatments of opthalmia. The roots are sweet, used in fevers, abdominal pain, palpitation of the heart and urinary troubles. They are useful in disorders like pitta and kapha. The wood is used for agricultural implements and timber. Leaves contain $0.6 \%$ essential oil composed of d-limonene, these are also used as fodder. Common varieties are 'Ayodhya', 'Dhar Road' 'Kagzi Baranasi', 'Kagzi Gonkda', 'KB- 1', 'KB- 11','Mirzapuri', 'Narendra Bael (NB) - I'(oblong), 'Narendra Bael (NB)- 2' (round), 'NB-5', 'NB-6' (round), 'Pant Aparna' (globose), 'Pant Shivani' (ovoid).

\section{Black turmeric (Curcuma caesia)}

A perennial herb of India with leaves having a deep violet red patch which runs through the length of the lamina. Flower petals are deep pink or red in colour. Rhizomes are bluish black in colour. It is useful in the treatment of piles, leprosy, bronchitis, asthma, cancer, epilepsy, fever, wounds, fertility, menstrual disorders, toothache, vomiting etc.

\section{Brahmi (Bacopa monnieri)}


This is a glabrous, creeping herb, leaves are oblong, spathulate and obtuse. The flowers are upto $1 \mathrm{~cm}$ in diameter, pale bluish, pimple veined, fading to white, arises from the axil of leaves and are borne on short pedicles. The roots appear from the nodes of the stem. The entire plant is used as drug. The plant is rich in brahmine, hespestine, saponins. This is an important drug in Ayurveda for the improvement of intelligence and memory and revitalisation of sense organs. It clears voice and improves digestion. It is recommended against dermatosis, anaemia, diabetes, cough, dropsy, fever, arthritis, anorexia, dyspepsia, emaciation, and insanity. It dispels poisonous affections, splenic disorders and impurity of blood. It is useful in vitiated conditions of kapha and vata, biliousness, neuralgia, ascites, flatulence, leprosy, leucoderma, syphilis, sterility and general debility. The plant is anti-cancerous and improves learning ability.

\section{Chingari (Clerodendrum indicum)}

This is an erect, less branched shrub, 1.5-3.0 $\mathrm{m}$ tall. The roots are light brown in colour and more than $2.5 \mathrm{~cm}$ in diameter. Stemis herbaceous, ridged, fluted, and hollow. Leaves are axillary, fascicled orterminal, and hang from the upright branches. Flowers of the species occur in axillary or terminal racemes. Fruit is upto $1.5 \mathrm{~cm}$ across, dark bluish green when ripe and seated on the enlarged red fleshy calyx.

The root contains sapogenins, saponins, triterpenes, and D-mannitol. The root of chingari is stomachic, expectorant, antiinflammatory, anti-bronchitis, febrifuge, hence useful for asthma, cough, and scrofulous affections. In Unani medicine, the root increases appetite and lowers fever. The leaves and roots are used externally to treattumours and certain skin diseases.

\section{Gandhli / prasdrani/ skunk vine (Paederia} foetida)

A twining vine like shrub with woody slender stems, $9 \mathrm{~m}$ long. The stems and leaves give off strong odour after bruishing. Leaves are evergreen, opposite, heart shaped with pointed tips, entire margin and long petioles. Flowers are short lived. Fruits are round and pea like. It grows well both in tropical and sub-tropical climate especially in wet warm and cool dry seasons. It can tolerate a temperature range of $3-22^{\circ} \mathrm{C}$. Grown upto an elevation of $2000 \mathrm{~m}$. It prefers a poorly drained sandy soils. Propagated by stem segments with a node or stolons. The major chemical constituent present in this plant are iridoid glycosides, sitosterol, stigmasterol, alkaloids, carbohydrates, protein, amino acid, dimethyl disulphide, and volatile oil. It is considered as alterative, anti-arthritic, antispasmodic, diaphoretic, hepato-protective, anti- ulcerous, vermifuge, anti-tumorous, expectorant and stomachic. The entire plant including stem, leaves and root are useful against asthma, rheumatism, paralysis, gout, toothache, piles and inflammation of liver and abscesses. A soup made from leaf is good for sick and convalescent. Leaves are used as a remedy for diarrhoea and dysentery.

\section{Giloe (Tinospora cordifolia)}

This is a gregarious glabrous, twinner grown well in tropical and subtropical climate. Older stems are up to $2 \mathrm{~cm}$ in diameter having corky bark. Aerial roots arise from nodal scars of branches. Stem and branches are specked with white vertical lenticels. Stem cuttings are the best planting material for raising commercial crop. The stems are rich in bitter substances, tinosporine. Other compounds include gilonin, gilosterol, gilenin, and furanoditerpenes. It is a tonic and has alterative, diuretic, and aphrodisiac properties. It is a febrifuge useful in malarial and chronic 
fever. It is also used a liver tonic. The plant is used in general debility, loss of appetite, fevers, urinary disorders, diabetes, rheumatism, and dyspepsia. Fresh plant is more efficacious than dried plant.

\section{Haritaki (Terminalia chebula)}

It is a medium sized deciduous tree with a cylindrical bole, rounded crown, spreading branches with dark brown bark and brownish gray heartwood. Leaves are simple, alternate or subopposite, ovate or elliptic ovate with short petioles bearing two glands below the blades. Flowers pale yellow or white, borne in axillary spikes. Fruit is a drupe, ovoid glossy, glabrous, faintly angled and yellow to orange brown in colour. Seeds are hard and pale yellow. In the natural habitat, the species grow at temperature ranges between $36{ }^{\circ} \mathrm{C}$ and $45^{\circ} \mathrm{C}$, and rainfall ranges from $1200 \mathrm{~mm}$ to $3000 \mathrm{~mm}$ per annum. It is suited for growing on different types of soils, but attains best development on loose well-drained soils, such as sandy loam as well as clayey loam. It grows in open areas in the forest, forming top to middle canopy. Seed is the most appropriate material for this plant's propagation.

About $5 \mathrm{~kg}$ seeds are required for raising stock for planting in one hectare of land. Approximately $40-50 \mathrm{~kg}$ of dry fruits are produced per tree per year after it attains six years of age. This gives an average yield of about 12.6 quintals/hectare. Kernel oil of Chebulicmyrobalana number of fatty acids viz. palmitic, stearic, oleic,linoleic, arachidic and behenic acid. The fruits are rich in chebulinic acid, tannic acid, gallicacid, chebulin and tannin. Leaves contain terpenes and saponins and beta-sitosterol is present inthe bark. The fruit is a common constituent of "Triphala" capable of imparting youthful vitality and receptivity of mind and sense. It is a major constituent in the ayurvedic preparations like Abhayarishta, Abhayamodak, Haritakikhand, Triphaladi churnam and Agastya rasayanam. In allopathy, it is usedin astringent ointments. In unani system, it is used as a blood purifier.

The pulp of the fruit is used in piles, chronic diarrhoea, dysentery, costiveness, flatulence, asthma, urinary disorders, vomiting, hiccup, intestinal worms, ascites and enlarged spleen and liver. Powder of the fruit is useful in chronic ulcers and wounds, carious teeth and bleeding ulceration of the gums. The bark is a good cardiac tonic.

\section{Heart leaf/ rainbow plant (Houttuynia cordata)}

A medicinal plant native to North-east India. It isan aromatic medicinal herb with creeping root stock, $20-50 \mathrm{~cm}$ in height with broad, ovate-cordate leaves. Rhizomes are creeping, thin while basal part of stems creeping rooted in whorls at nodes, apical part erect, glabrous or pubescent on nodes, sometimes purplish red. Whole plant is eaten raw as a medicinal salad for lowering the blood sager level.

Leaf juice is consumed for the treatment of cholera, dysentery, curing of blood deficiency and purification of blood. Young shoots and leaves are eaten raw or cooked as a pot-herb. A decoction of this plant is used internally for the treatment of many diseases including cancer, coughs, dysentery, enteritis and fever. Externally, it is used for the treatment of snake bites and skin disorders.

\section{Indian gentian (Gentiana kurroo)}

It is a small perennial herb up to $30 \mathrm{~cm}$ height with tufted decumbent stems. Flowers are blue with white spots, $4.5 \mathrm{~cm}$ long and $2.5 \mathrm{~cm}$ in diameter. Fruits are $2 \mathrm{~cm}$ long. Naturally distributed to north-western Himalayas between 1,500-3500 metres altitude in 
Garhwal, Kashmir and adjoining hills. Rhizomes and roots are used for medicinal purposes. They contain bitter glycosides like gentiopicrin, gentianin and gentiomarin. The rootstocks are used as bitter tonic, antiperiodic, expectorant, antibilious, astringent, stomachic, anthelmintic, blood purifier and carminative. It is used for curing skin diseases, bronchial asthma and urinary infections. It is also used for improving appetite, stimulating gastric secretion and in the treatment of digestive disorders.

\section{Kalmegh (Andrographis paniculata)}

It is an erect branched annual herb, 0.3-0.9m tall with quadrangular branches. Leaves are simple, lanceolate, acute at both ends, glabrous, with 4-6 pairs of main nerves. Flowers are small, pale but blotched and spotted with brown and purple distant in lax spreading axillary and terminal racemes or panicles. Calyx-lobes are glandular pubescent with anthers bearded at the base. Fruits are linear capsules and acute at both ends. Seeds are numerous, yellowish brown and subquadrate. Leaves are rich in "andrographolid" and "kalmeghin".

The ash contains sodium chloride and potassium salts. Plant is very rich in chlorophyte. Kalmeghin is the active principle that contains $0.6 \%$ alkaloid of the crude plant. It is useful in hyperdipsia, burning sensation, wounds, ulcers, chronic fever, malarial and intermittent fevers, inflammations, cough, bronchitis, skin diseases, leprosy, pruritis, intestinal worms, dyspepsia, flatulence, colic, diarrhoea, dysentery, haemorrhoids and vitiated conditions of pitta. It is used to overcome sannipata type of fever, difficulty in breathing, hemopathy due to the morbidity of kapha and pitta, burning sensation, cough, oedema, thirst, skin diseases, fever, ulcer and worms. It is also useful in acidity and liver complaints.

\section{Kuchla (Strychnos nux vomica)}

It is a medium-sized, deciduous tree, with fairly straight and cylindrical bole and darkgrey or yellowish-grey bark with minute tubercles. Leaves are simple, opposite, orbicular to ovate, coriaceous, glabrous, and five-nerved. Flowers are white or greenish white and fragrant. They appear in many flowered terminal cymes. Fruit is an indehiscent berry, thick shelled, orange-red when ripe with fleshy pulp. The plant grows well in dry or humid tropical areas of the country. It thrives over laterite, sandy, and alluvial soils. Seeds are the best material for propagation of kuchila tree.

The collected seeds are dried in the sun after removing the pulp. Preferably, fresh seeds are used. The plant can also be propagated through cuttings. About $1 \mathrm{~kg}$ seeds are required to raise one hectare of plantation. Strychnine and brucine are the most important alkaloids present in the plant. They are found not only in the seeds but also in roots, wood, bark, fruit pulp and hard fruit shells. The minor alkaloids present in the plant are vomicine, alpha-colubrine, beta-colubrine, pseudostrychnine and N-methyl-secpseudobrucine (novacine).in small doses it can also serve as efficacious cure forms of paralysis and other nervous disorders.

The seeds are used as a remedy in intermittent fever, dyspepsia, chronic dysentery, paralytic and neuralgic affections, worms, epilepsy, chronic rheumatism, insomnia and colic. It is also useful in impotence, neuralgia of face, heart disease, spermatorrhoea, skin diseases, toxins, wounds, emaciation, cough and cholera. Leaves are applied as poultice in the treatment of chronic wounds and ulcers and the leaf decoction is useful in paralytic complaints. Root and root bark useful in fever and dysentery. 


\section{Mishmi teeta (Coptis teeta)}

It is hardy evergreen bog plant and a small stemless herb. Leaves are compound and glabrous. Flowers are small, regular, white in colour. Fruits are many seeded follicles and seeds are black in colour. It requires temperate climate, moist soils and shady locations. The dried rhizomes constitute the drug. It contains alkaloids of berberine group. It is tonic and stomachic. The rhizome is administered in intermittent fever and debility.

\section{Neem (Azadirachta indica)}

Neem is a hardy medium to large, mostly evergreen tree, $20 \mathrm{~m}$ tall and $2.5 \mathrm{~m}$ girth. It has a short bole with wide spreading branches and glabrous twigs forming a round to oval crown. The bark is thick, dark-grey with numerous longitudinal furrows and transverse cracks. Leaves are imparipinnately compound and $20-38 \mathrm{~cm}$ long. Inflorescence is long, slender, axillary or terminal panicle. Flowers are white or pale yellow, small, bisexual, pentamerous and bracteate. Fruit is one seeded drupe with woody endocarp, greenish yellow when ripe. Seeds are ellipsoid, cotyledons thick fleshy and oily. Neem grows well in tropical arid regions with high temperatures, altitudes between $50 \mathrm{~m}$ and $1000 \mathrm{~m}$. Leaves contain the flavanoidquercetin, nimbosterol $\quad(\square-$ sitosterol), kaempferol and myricetin. Seed and oil contains desacetylnimbin, azadirachtin (C35H44O16), nimbidol, meliantriol, tannic acid, $\mathrm{S}$ and amino acids. Trunk barks are rich in nimbin, nimbinin, nimbidin, nimbosterol, essential oil, tannins, margosine and desacetylnimbin. Every part of the tree, namely root, bark, wood, twig, leaf, flower, fruit, seed, kernel and oil has been in use from time immemorial in the Ayurvedic and Unani systems of medicine. Nimbarishta, nimbadichurna and nimbharidrakhand are well known preparations. It is valuable as an antiseptic, used in the treatment of small pox. Small twigs are used as tooth brushes and as aprophylactic for mouth and teeth complaints. Extract from the leaves are useful for sores, eczema and skin diseases. Boiled and smashed leaves serve as excellent antiseptic. Decoction of leaves is used for purifying blood. Neem oil is used in soaps, toothpaste and asa hair tonic to kill lice. Seed is used in snake bite. Extracts of neem seed oil and bark check the activity of male reproductive cells and prevents sperm production. Neem seed oil is more effective than thebark for birth control. Neem based commercial products are also available for diabetes treatment (Nimbola, JK-22), contraceptive effect (Sensal, Nim-76) and mosquito/ insect repelling.

\section{Safed musli (Chlorophytum arundinaceum)}

It is a rhizomatous herb. The leaves are suberect, lanceolate and many nerved. The inflorescence is an erect, dense-flowered raceme. The flowers are star like, white up to $2 \mathrm{~cm}$ across, sepals are acute, anthers are longer than filaments and green or yellow in colour, bracts are long. Seeds are black in colour with angular edges. The dry roots contain carbohydrates, proteins, root fibres, saponins and minerals. It is a well-known tonic and aphrodisiac and used to treat general debility. Leaves are eaten as vegetable. The tubers of about $20 \mathrm{~g}$ is boiled with milk and taken twice a day for a month in cases of impotency and weakness.

\section{Tulsi (Ocimum sanctum)}

It is an erect, much branched subshrub, 30$60 \mathrm{~cm}$ tall with simple opposite green or purple leaves. It is recommended for the treatment of bronchitis, malaria, diarrhea, dysentery, skin disease, arthritis, eye diseases, insect bites and so on. The $O$. sanctum $\mathrm{L}$. is 
also suggested to possess anti-fertility, anticancer, antidiabetic, antifungal, antimicrobial, cardioprotective, analgesic, antispasmodic and adaptogenic actions. Eugenol, the active constituents present in $O$. sanctum $\mathrm{L}$. have been found to be largely responsible for the therapeutic potentials.

\section{Turmeric (Curcuma longa)}

A perennial herb, $1 \mathrm{~m}$ long with tufted leaves and a short and thick rhizome. Leaves are long, pointed and lengthy and rectangular in shape. Flowers are funnel shaped and yellow in colour. Rhizomes are $2.5-7.5 \mathrm{~cm}$ in length and $1 \mathrm{~cm}$ in diameter. It requires a tropical humid climate with a rainfall of $1500-2000 \mathrm{~m}$ and $18-30^{\circ} \mathrm{C}$ temperature. Turmeric contains $5 \%$ essential oils and upto $7.3 \%$ curcumin, a polyphenol.

It exists in two tautomeric forms, keto and enol. It is used as a culinary ingredient. It is used as food colouring component for curry and as a preservative for food. Traditionally, it is used as a medical herb due to its antioxidant, anti-inflammatory, antimutagenic, antimicrobial and anticancer properties. It is used in the treatment of stomachache, skin problems and arthritis. It has been used as clothing dye and as a cosmetic. In China, it is used as analgesic and for colic, hepatitis, ringworms and chest pain. In Europe, it is used for colouring in mustard, cheese, margarion, beverages and cakes.

Recently, it is used for dyspepsia, chronic anterior uvetis and Helicobacter pylori bacteria. Otherwise, it is antiseptic for cuts, burns and bruises. In South India, turmeric plant leaf is used to prepare special sweet dishes by covering rice fluor, jaggery, coconut and cooked in steam. Popular varieties are 'Kedaram', 'Kranti', 'Krishna', 'Megha Turmeric-1', 'Prabha', 'Pratibha', 'Rajendra Sonia', 'Ranga', 'Rasmi', 'Roma', 'Sobha', 'Sona',
'Sudarsana', 'Sugandham', 'Suguna', 'Suranjana', 'Suvarna', 'Lakhadong', 'Varna'.

\section{Vasak (Adhatoda vasica)}

It is an evergreen shrub grown upto one metre in height with many long opposite branches. Leaves are large and lance-shaped. Stems are herbaceous above and woody below. Leaves are opposite and exstipulate. Flower arespikes or panicles, small irregular zygomorphic, bisexual, and hypogynous. It has capsular four seeded fruits. The flowers are either white or purple in colour. It is propagated by tender stem cuttings. Stem cuttings of 15$20 \mathrm{~cm}$ long and 3-4 nodes are ideal for planting. The plants contain vasicine, vasicinone, deoxyvasicine, maiontone, vasicinolone and vasicinol. The leaves, flowers, fruit and roots are extensively used for treating cold cough, whooping cough, chronic bronchitis and asthma, as sedative, expectorant and antispasmodic.

\section{Wild turmeric (Curcuma aromatica)}

It is a herbaceous perennial plant producing clumps of erect, unbranched leaf stems, about 1 metre tall from a stout, underground rhizome. The inflorescences usually appear from the rhizomes before the leaves are produced. Wild Turmeric is extensively used as an aromatic medicinal cosmetic in India. The plant has been in traditional use and in Ayurvedic literature it is mentioned as a remedy for various diseases related to skin, cardiovascular and respiratory system. Some of them include anti-inflammatory, wound healing, anti-melanogenic, antioxidant and free radical scavenging activity, anti-tumor, anti-cancer, anti-repellent, antitussive, antiplatelet activity and antinephrotoxic activity.

\section{References}

De, L.C. 2017. 'Cultivation and Breeding of 
Medicinal and Aromatic Plants', p. 432 Published by Pointer Publisher, Jaipur, Rajasthan.

De, L. C. and Bhattacharjee, S.K. 2010. 'Handbook of Vegetable Crops', Published by Pointer Publisher, Jaipur, Rajasthan, Pp. 508.

De, L.C. and Bhattacharjee, S.K. 2008. 'Hand Book of Edible Fruits'. Published by Pointer Publisher, Jaipur, Rajasthan. Pp. 510.

Elbert, A.W. 2014. Potential of Underutilized

Traditional Vegetables and Legume
Crops to Contribute to Food and Nutritional Security, Income and More Sustainable Production Systems. Sustainability, 6: 319-335.

Keatinge, J.D.H., Yang, R.-Y., Hughes, J.d'A., Easdown, W.J. and Holmer, R. 2011.The importance of vegetables in ensuring both food and nutritional security in attainment of the Millennium Development Goals. Food Sci. 3: 491501.

\section{How to cite this article:}

De, L. C. and Tulipa De. 2020. Indigenous Horticultural Crops of India for Immunity Development. Int.J.Curr.Microbiol.App.Sci. 9(06): 3068-3089.

doi: https://doi.org/10.20546/ijcmas.2020.906.369 